\title{
TUNICA VAGINALIS FLAP (TVF) AS AN ALTERNATIVE TO DARTOS FLAP IN PRIMARY HYPOSPADIAS REPAIR- OUR EXPERIENCE
}

\author{
Vishal Gajbhiye1, Nagendra Singh², Sona Singh ${ }^{3}$, R. S. Verma ${ }^{4}$
}

${ }_{1}^{1}$ Assistant Professor, Department of Surgery, Bundelkhand Medical College and Hospital, Sagar, Madhya Pradesh.

${ }_{2}^{2}$ Associate Professor, Department of Surgery, Bundelkhand Medical College and Hospital, Sagar, Madhya Pradesh.

${ }_{3}^{3}$ Assistant Professor, Department of Obstetrics and Gynaecology, Bundelkhand Medical College and Hospital, Sagar, Madhya Pradesh. 4 Professor and HOD, Department of Surgery, Bundelkhand Medical College and Hospital, Sagar, Madhya Pradesh.

\section{BACKGROUND}

ABSTRACT

Hypospadias is one of the common anomalies in boys. No single technique is considered perfect for hypospadias repair, it lead to many techniques described for its repair. Post-operative fistula formation is the commonest complication of hypospadias surgery and this complication usually requires further surgeries. To avoid this complication, various soft tissue interposition grafts are introduced. Tunica vaginalis flap is one of them. Tunica vaginalis has extra-penile vascularity, hence helping in healing of suture line of neourethra. We plan a comparative prospective study of tunica vaginalis flap and Dartos flap over two years, which show good results with TVF with significant decrease of urethrocutaneous fistula rate. TVF is a viable option as compared to Dartos flap in primary repair of hypospadias.

\section{MATERIALS AND METHODS}

Study was conducted for 2 years in total 48 patients. 24 patients (Group A), who were candidates for a primary single-stage urethroplasty were prospectively chosen for TVF repair as soft tissue cover. Patients of equal number, who were comparable in age and type of hypospadias were taken as controls (Group B) operated with using Dartos flap as soft tissue cover.

\section{RESULTS}

All patients in Group A were repaired successfully. Only one patient developed superficial wound dehiscence and treated conservatively. No fistula was noted in any of the patients in this group. In Group B Fistula developed in 3 patients, which required delayed closure later on. Three patients developed localised superficial necrosis of the ventral penile skin, which was managed conservatively.

\section{CONCLUSION}

Tunica vaginalis flap (TVF) is a viable option as compared to Dartos flap in primary repair of hypospadias.

\section{KEYWORDS}

Hypospadias, Fistula, Tunica Vaginalis Flap.

HOW TO CITE THIS ARTICLE: Gajbhiye V, Singh N, Singh S, et al. Tunica vaginalis flap (TVF) as an alternative to dartos flap in primary hypospadias repair- our experience. J. Evolution Med. Dent. Sci. 2018;7(16):1970-1973, DOI: 10.14260/jemds/2018/443

\section{BACKGROUND}

Hypospadias is one of the common anomalies in boys. No single technique is considered perfect for hypospadias repair, it lead to many techniques described for its repair.[1] Postoperative fistula formation is the commonest complication of hypospadias surgery and this complication usually required further surgeries. Several techniques of providing vascularised soft tissue cover to the neourethra have been described. Many efforts for prevention of fistulae are undertaken like better suture materials, use of magnification, dorsal subcutaneous flap, silicone stents and catheters.[2] Both Dartos fascia and tunica vaginalis provide robust cover to the urethra and act as a barrier between the suture lines. The tunica vaginalis flap (TVF) has good vascularity, its blood supply also come from different source and does not depend on penile skin vascularity unlike the Dartos fascia.

'Financial or Other Competing Interest': None.

Submission 26-02-2016, Peer Review 01-04-2018,

Acceptance 09-04-2018, Published 16-04-2018.

Corresponding Author:

Dr. Nagendra Singh,

Flat No. 6, Block 1,

BMC Campus, Sagar-470001, Madhya Pradesh.

E-mail: drnagendra.804@gmail.com

DOI: $10.14260 /$ jemds $/ 2018 / 443$

\section{(c) $(1) \ominus$}

So, a study is conducted in our institute (BMC, Sagar, M. P.) to compare the post-operative fistula rate of Dartos and tunica vaginalis flap for hypospadias repair.

\section{MATERIALS AND METHODS}

Study Design- Non-randomised controlled trial.

Study Period- 02 years.

\section{Study Population}

Cases of hypospadias undergoing a primary single-stage urethroplasty in BMC Hospital, Sagar in stipulated time period.

Study Area- BMC Hospital, Sagar, M. P.

Study Tools- Checklist of post-operative complications, history and clinical examination of the patient operated.

\section{Sample Allocation}

All the cases of hypospadias coming to hospital and undergoing operating procedure mentioned above during the study period. 


\section{Sampling Method}

Consecutive/purposive sampling (All the patients of hypospadias coming to hospital and giving consent for operating procedure).

\section{Inclusion Criteria}

- Distal penile or mid-penile hypospadias.

- With or without chordee.

- $\quad$ Age more than 18 months.

\section{Exclusion Criteria}

- Recurrent case/previous hypospadias surgery (Redo cases).

- Previous inguino-scrotal surgery, i.e. hernia or hydrocele repair or orchidopexy.

\section{Confounding Factors}

- Chordee.

- $\quad$ Type of Hypospadias.

\section{Sample Allocation}

Allocation of subjects into the two groups: each next patient was kept into the second group/ alternate operating procedure.

Till the duration of study period of 02 years, a total of 48 cases of hypospadias were operated. All the patients were comparable in age (childhood period) and type of hypospadias and candidate for a primary single-stage urethroplasty. Group A (24 patients) underwent Tunica Vaginalis Flap (TVF) repair as soft tissue cover after urethroplasty. Group B (other 24) operated with using Dartos flap as soft tissue cover after urethroplasty.

\section{Statistical Tests}

Fisher's exact test using SPSS version 20 (as one group contain numerical value below 5 ).

\section{RESULTS}

Among 48 cases of hypospadias who underwent primary single-stage urethroplasty, 24 cases underwent Tunica Vaginalis Flap (TVF) repair as soft tissue cover after urethroplasty (Group A) and other 24 operated using Dartos flap as soft tissue cover after urethroplasty (Group B).

Hypospadias type varied from distal penile to mid-penile hypospadias in similar distribution in both the groups. Twenty patients in Group A and 19 patients in Group B had chordee on examination. Detailed distributions are shown in Table 1 to Table 4.

\begin{tabular}{|c|c|c|c|}
\hline Type & A & B & Total \\
\hline Distal penile & 20 & 20 & 40 \\
\hline Mid penile & 4 & 4 & 08 \\
\hline Total & $\mathbf{2 4}$ & $\mathbf{2 4}$ & $\mathbf{4 8}$ \\
\hline \multicolumn{2}{|c|}{$\mathrm{p}=1.299$ Not significant by Fisher's Exact test } \\
\hline \multicolumn{4}{|c|}{ Table 1. Distribution of Patients according to Type of } \\
Hypospadias \\
\hline
\end{tabular}

\begin{tabular}{|c|c|c|c|}
\hline Chordee & A & B & Total \\
\hline Yes & 20 & 19 & 39 \\
\hline No & 4 & 5 & 9 \\
\hline Total & $\mathbf{2 4}$ & $\mathbf{2 4}$ & $\mathbf{4 8}$ \\
\hline \multicolumn{2}{|c|}{ p=1.00, Not significant by Fisher's Exact test } \\
\hline Table 2. Distribution of Patients according to Presence of \\
Chordee \\
\hline
\end{tabular}

\begin{tabular}{|c|c|c|c|}
\hline Post-Op Fistula & A & B & Total \\
\hline Yes & 0 & 3 & 3 \\
\hline No & 24 & 21 & 45 \\
\hline Total & $\mathbf{2 4}$ & $\mathbf{2 4}$ & $\mathbf{4 8}$ \\
\hline \multicolumn{3}{|c|}{ p = 0.234, Not significant by Fisher's Exact test } \\
\hline \multicolumn{4}{|c|}{ Table 3. Distribution of Patients according to Post- } \\
Operative Fistula \\
\hline
\end{tabular}

\begin{tabular}{|c|c|c|c|}
\hline $\begin{array}{c}\text { Post-Operative } \\
\text { Complications }\end{array}$ & A & B & Total \\
\hline Present & $\begin{array}{c}5 \\
\text { (Ventral penile } \\
\text { tilt- } 4 \\
\text { Superficial } \\
\text { wound } \\
\text { dehiscence- 1) }\end{array}$ & $\begin{array}{c}3 \\
\text { (Superficial } \\
\text { skin } \\
\text { necrosis- 3) }\end{array}$ & 08 \\
\hline Not Present & 19 & 21 & 40 \\
\hline Total & 24 & 24 & 48 \\
\hline \multicolumn{4}{|c|}{$p=0.700$, Not significant by Fisher's Exact test } \\
\hline \multicolumn{4}{|c|}{$\begin{array}{l}\text { Table 4. Distribution of Patients according to other Post- } \\
\text { Operative Complications }\end{array}$} \\
\hline
\end{tabular}

In both the groups, patients chosen were where a tubularised incised plate (TIP) repair was possible.

\section{Operative Technique}

Basic steps of surgery were same in both the groups. Tubularisation of urethral plate was done over an optimal sized catheter using 5-0 polyglactin suture. All precautions were taken to exclude epithelium in the bites, thus ensuring epithelium inversion toward the urethral lumen. Soft tissue coverage technique differed among the groups over the neourethra.

In Group A, TVF was harvested by opening the one side of hemiscrotum bringing out the testis with its covering and cord into the operative field. Tunica vaginalis flap was raised off by incising tunica vaginalis near testicular lower pole and expanded upto the cord structures, taking care to avoid damage to the vas and vessels. Sufficient length of the flap was raised depending on variety of hypospadias even up to the external ring. After adequate haemostasis, testis was put back in the scrotum. The TVF was then put over the neourethra to provide a cover along the whole length.

In Group B, the Dartos flap was used to provide soft tissue cover over neourethra. It was harvested from the dorsal prepuce and the penile skin with careful dissection between the Dartos and the skin. The Dartos fascia was then mobilised ventrally over the ventral suture line and tacked with 5-0 polyglactin sutures.

Light compression dressing was done. Intravenous antibiotics coverage was given for 5 days followed by oral antibiotics. Dressing and the catheter were removed on the $7^{\text {th }}$ day. Periodic follow-up was done thereafter. 


\section{RESULTS}

The results are summarised in Table 1 to Table 4 . There were 24 patients in Group A with a mean age of 20 months (range: 18 - 36 months). 20 patients had distal penile hypospadias and 4 mid-penile hypospadias. Chordee was present in 20. All patients were repaired successfully in this group. Only one patient developed superficial wound dehiscence, treated conservatively. No fistula was noted in any of the patients in this group.

The mean age in Group B was 22 months (range: 18 - 52 months). 20 patients had distal penile hypospadias and 4 mid-penile hypospadias. In all the patients, TIP was done. Fistula developed in 3 patients, which required delayed closure later on. Three patients developed localised superficial necrosis of the ventral penile skin, which were managed conservatively.

Follow-up was from 6 to 18 months in both the groups. There was no incidence of fistula, meatal stenosis or testicular ascent in this period in Group A. Three patients in Group B, who had fistula required reoperation and have been doing well since then.

Confounding factors like presence of chordee and type of hypospadias showed no statistical significance in both the groups.

On Fisher's Exact test both the groups have no statistical significance, showing both the techniques are equally effective.

\section{DISCUSSION}

Hypospadias is one of the common anomalies in boys. No single technique is considered perfect in hypospadias correction lead to evolution of many techniques.[1] Postoperative fistula being the most common complication of hypospadias repair. To reduce post-operative fistula rate various technical modifications are made like use of fine suture materials, magnification use, dorsal subcutaneous flap, silicone stents and catheters.[2]

Snodgrass ${ }^{[3]}$ dissected subcutaneous tissue from dorsal prepucial and shaft skin to provide additional coverage of neourethra. Duckett[4] has described that when Dartos is separated from skin, it compromises the vascularity of the overlying skin. There are various options for soft tissue coverage available, but none is devoid of post-operative fistula risk.

Success of hypospadias surgery is judged by incidence of fistula.[5] Durham Smith in a study of hypospadias surgery noted varied fistula rates for different procedures.[6] Flip-flap repair varied from 2.2 to $35 \%$, island pedicle tube flap 4 to $35 \%$, free graft tube flap had a fistula rate of 15 to $50 \% .{ }^{[6]}$ Durham Smith had a fistula rate of $3 \%$ in 500 cases. ${ }^{[7]}$

Snow et al[8] in 1995 were the first to describe the use of tunica vaginalis as soft tissue interposition graft. They reported $9 \%$ fistula rate in their study. Advantage of tunica vaginalis flap are its easy availability and its excellent vascularity, which is separate from penis. Furthermore, because this tissue is separate from the penis, disorders of penis does not affect tunica vaginalis flap. Furthermore, in redo cases tunica vaginalis flap has excellent outcome. ${ }^{[8]}$ In recent results, Snodgrass showed $0 \%$ fistula rate with the use of TVF.[9]
In our study, four cases in Group A had mid-penile hypospadias. They had long ventral urethral suture line. Despite the long suture line, no fistula occurred in any of these cases due to the robust soft tissue cover. Harvesting TVF was easy in these cases, as the ventral incision on the penis as such extended very close to the scrotum. Since TVF does not depend on the penile skin, the ventral skin cover is never compromised.

None of the cases in Group A had any fistula during follow-up. Three fistulas occurred in Group B, which required surgery later on for fistula closure.

Chatterjee et al[10] compared these two methods of soft tissue cover previously. They have done a prospective study and compared the Dartos flap and tunica vaginalis flap as neourethral coverage after a TIP procedure. They have concluded that TIP with TVF could be an alternative to other techniques in a primary case of hypospadias. In their study, the fistula rate for cases with TVF were $0 \%$ and for Dartos flap were $15 \%$ - 20\%. Our study also has comparable results with fistula rate for $0 \%$ and $12.5 \%$ for TVF and Dartos flap respectively. Other complications which were observed in our series are 3 cases of superficial skin necrosis following Dartos flap, which responded to conservative management. Complications which we observed with tunica vaginalis flap are 4 of our cases showed mild ventral tilt of penis, all the tilt cases were observed in distal penile hypospadias variety. It may be due to fibrosis of TVF after some time, which lead to bowstring effect over ventral aspect of penis.

\section{CONCLUSION}

Tunica vaginalis flap as interposition cover of neourethral tube helps in reduction of fistulae rate in variety of hypospadias procedures with minimal complication rate as compared to Dartos flap. TVF is a viable option as compared to Dartos flap in primary repair of hypospadias.

\section{REFERENCES}

[1] Smith D. A de-epithelialised overlap flap technique in the repair of hypospadias. $\mathrm{Br} \mathrm{J}$ Plast Surg 1973;26(2):106-14.

[2] Retik AB, Keating M, Mandell J. Complications of hypospadias repair. Urol Clin North Am 1988;15(2):223-36.

[3] Snodgrass W. Tubularized, incised plate urethroplasty for distal hypospadias. J Urol 1994;151(2):464-5.

[4] Duckett JW. Hypospadias. In: Walsh PC, Retik AB, Vaughan ED, et al. (eds). Campbell's urology. $7^{\text {th }}$ edn. Philadelphia: WB Saunders Company, 1998:2094-116.

[5] Durham SE. Hypospadias. In: Ashcraft K. (eds) Pediatric urology. Philadelphia; WB Saunders, 1990:353-95.

[6] Shapiro SR. History of hypospadias repair, reconstructive and plastic surgery of the external genitalia adult and pediatric. WB Saunders Company, 1999:pp 132.

[7] Smith ED. Durham smith repair of hypospadias. Urol Clin North Am 1981;8(3):451-5.

[8] Routh JC, Wolpert JJ, Reinberg Y. Tunneled tunica vaginalis flap is an effective technique for recurrent urethrocutaneous fistula following tubularized incised plate urethroplasty. J Urol 2006;176(4 Pt 1):1578-80. 


\section{Jemds.com}

[9] Snodgrass W, Yucel S. Tubularized incised plate for mid shaft and proximal hypospadias repair. J Urol 2007;177(2):698-702.
Original Research Article

[10] Chatterjee US, Mandal MK, Basu S, et al. Comparative study of dartos fascia and tunica vaginalis pedicle wrap for the tubularized incised plate in primary hypospadias repair. BJU Int 2004;94(7):1102-4. 